\title{
Temporal and spatial distribution fatal occupational injuries in Ecuador
}

\section{Distribución temporal y espacial fatal de lesiones ocupacionales en el ecuador}

Vilaret Serpa A.

Silva Peñaherrera G M.

Merino Salazar P.

Suasnavas Bermudez P R.

Gómez García A R.

Universidad Internacional SEK Ecuador, Ecuador

Espinoza Samaniego Ce.

Universidad de Especialidades Espíritu Santo, Ecuador

Autor para correspondencia: antonio.gomez@uisek.edu.ec

Fecha de recepción: 09 de Mayo de 2017 - Fecha de aceptación: 10 de Mayo de 2017

Abstract: Ecuador is a country in South America, divided geographically by the Andean Mountain Range. With the approval of the Resolution No C.D. 333 in 2010, companies are compelled to report all occupational accidents and diseases to the corresponding Occupational Health Public Organisms. Currently, there are no studies on the geographic and temporal distribution of deadly occupational accidents in the country. The objective of this study was to determine the temporal and geographic distribution of fatal occupational accidents (FOA) in Ecuador. Ecologic Study of temporal and geographical distribution of FOA in the 24 provinces of Ecuador between 2010 and 2016. Data was obtained thru official secondary information sources. Gross and Adjusted Mortality Rates were calculated for workers affiliated to the General Mandatory Insurance, allowing the space representation in terms of the object of study. During the period analyzed, 1.748 workers have passed due to work related accidents in Ecuador. The Gross Mortality Rate (x100.000-affiliated workers) presents a decreasing tendency from 2010 (13.2) to 2014 (6.3), increasing for 2015 (9.5). The main provinces with a higher Adjusted Mortality Rate (x10.000-affiliated workers) are located in the Amazon Region: Morona Santiago, Napo, Orellana and Sucumbíos. Ecuadorian Geography implies important differences in terms of FOA distribution by provinces and the compliance of legal norms in Safety and Occupational Health thru time. The temporal distribution and geographic representation of this phenomenon will allow the corresponding public control entities to identify provinces with high mortality rates and implement specific actions to prevent. The results of this study will help establish future research lines that will analyze more in depth this issue.

Key words: occupational accidents; mortality rate; geography; ecuador

Resumen: Ecuador es un país de América del Sur, dividido geográficamente por la Cordillera Andina. Con la aprobación de la Resolución C.D. 333 en 2010, las empresas se ven obligadas a denunciar todos los accidentes y enfermedades profesionales a los correspondientes Organismos Públicos de Salud Ocupacional. Actualmente, no existen estudios sobre la distribución geográfica y temporal de los accidentes laborales letales en el país. El objetivo de este estudio fue determinar la distribución temporal y geográfica de los accidentes de trabajo mortales (FOA) en Ecuador. Estudio Ecológico de la distribución temporal y geográfica de FOA en las 24 provincias de Ecuador entre 2010 y 2016. Los datos se obtuvieron a través de fuentes oficiales de información secundaria. Las Tasas de Mortalidad 
Bruta y Ajustada fueron calculadas para los trabajadores afiliados al Seguro General Obligatorio, permitiendo la representación espacial en función del objeto de estudio. Durante el período analizado, 1.748 trabajadores han pasado por accidentes laborales en Ecuador. La Tasa Bruta de Mortalidad (x100.000 trabajadores afiliados) presenta una tendencia decreciente desde 2010 (13.2) a 2014 (6.3), aumentando para 2015 (9.5). Las principales provincias con mayor Tasa de Mortalidad Ajustada (x10.000 afiliados) se ubican en la Región Amazónica: Morona Santiago, Napo, Orellana y Sucumbíos. La geografía ecuatoriana implica importantes diferencias en términos de distribución de FOA por provincias y el cumplimiento de las normas legales en Seguridad y Salud Ocupacional a través del tiempo. La distribución temporal y la representación geográfica de este fenómeno permitirán a las correspondientes entidades de control público identificar las provincias con altas tasas de mortalidad e implementar acciones específicas de prevención. Los resultados de este estudio ayudarán a establecer futuras líneas de investigación que analizarán más a fondo esta cuestión.

Palabras clave: accidentes de trabajo; tasa de mortalidad; geografía; ecuador

\section{Introduction}

Ecuador is geographically located in the north occidental coast of South America, bordering with Colombia to the North and Peru to the South. Its territory is divided into 24 provinces [1].

Ecuadorian Society is characterized by its social, ethnic and regional diversity, mainly due to the Andean Mountains, which divide the country in three geographic areas: Coastal Region, Andean Region and Amazon Region, and a fourth Insular Region (Galapagos Islands) [2].

Furthermore, important differences exist in terms of economic activities distribution and the workforce by region, $53 \%$ is concentrated in the Andean Region, $42 \%$ in the Coastal Region, 4.6\% in the Amazon Region and $0.4 \%$ in the Galapagos Islands. The main economic activities in the country [3] are wholesale and retail commerce, manufacturing industries, and social services and health activities.

According to the International Labor Organization (ILO), 2.3 million people die every year due to work related accidents and diseases, estimating a direct and indirect cost of 2.8 billion of dollars [4], amount that was qualified as unacceptable in the XX Worldwide Congress of Safety and Occupational Health in 2014 hosted in Frankfurt Germany [5].

For Latinamerican and Caribbean Countries, the available data show there are 11.1 registered fatal accidents per 100.000 workers. In this sense, ILO recommends to promote effective inspection systems to ensure the compliance of national policies [6] since they cause an economic impact in the productivity of businesses [7-9] and a public health constraint for the countries [11-12].

In the last years, a tendency to investigate labor accidents from different approaches exists (causes, consequences, economic activities, etc.). Nevertheless, the analysis must not only focus in statistical data but also in a spatial perspective, that includes geographic distribution to the problem of study $[18 ; 20]$. 
In Ecuador, with the approval of the Resolution No C.D. 333 - Regulations for the Audit System of Occupational Risks in the year 2010, the obligation to notify the occurrence of occupational accidents or diseases to the Ecuadorian Social Security Institute (IESS) was reinforced; marking a starting point and occasion for the analysis of the work related accident rates.

The objective of the current study was to determine the temporal and geographical distribution of fatal work injuries between 2010 and 2016.

\section{Material - Methods}

Ecologic Study of temporal and geographical distribution of fatal work injuries (ATM) between 2010 and 2016. ATM Data was obtained on the webpage of the General Occupational Risks [22] Insurance belonging to IESS.

Based on this information, the variables were grouped by work injuries, geographic distribution of the 24 provinces by region and time components for the period of study.

Afterwards, relative data was obtained on the number of workers affiliated to the Mandatory General Insurance [23-24] per province per year, permitting the calculation the Gross Mortality Rate (x100.000-affiliated workers) and the Adjusted Rate per Province (x10.000affiliated workers).

Finally, the procedure for the statistics analysis employed absolute and relative frequencies, averages, maximums-minimums, variation percentage compared to prior years, lineal tendency (R2) and a geographic representation of the Mortality Rate by province.

\section{Results}

Table 1 shows the distribution of FOA and affiliated workers by province and year. During the period of the study, there have been 1.748 casualties due to work related accidents according to the statistics generated by the Occupational Risks General Insurance from IESS, with an average of $250 \pm 33$ deaths per year.

2015 stands out $(\mathrm{n}=298)$ for being the year with the greater number of FOA and Pichincha $(n=406 ; 23,2 \%)$, Guayas $(n=392 ; 22,4 \%)$, El Oro $(n=119 ; 6,8 \%)$ and Manabí $(n=113$; $6,5 \%)$ as provinces with higher number of fatalities. The Gross Mortality Rate presents a decreasing tendency from 2010 (13.2) to 2014 (6.3), raising in 2015 (9.5).

In terms of the temporal distribution, Figure 1 shows a decrease of FOA from 2012 to 2013 (-1,4\%; -1,9\%), remaining stable for 2014 with 215 deaths. Nevertheless, in 2015 a $4.7 \%$ increase with respect to the prior year is observed. Finally, we can see a fatality reduction tendency $\left(\mathrm{R}^{2}=0,097\right)$, predicting 216 FOA for the year 2020 .

With respect to the geographic distribution of FOA, Figure 2 shows in a scale of colors the provinces with higher Adjusted Mortality Rates for 2010 nationwide. The higher rates 
correspond to the provinces of Azuay $(4,5)$, Bolívar $(3,6)$ and Cañar $(2,4)$. For 2011 these provinces also lead the Mortality Rate $(8,6 ; 3,8 ; 3,2)$, respectively.

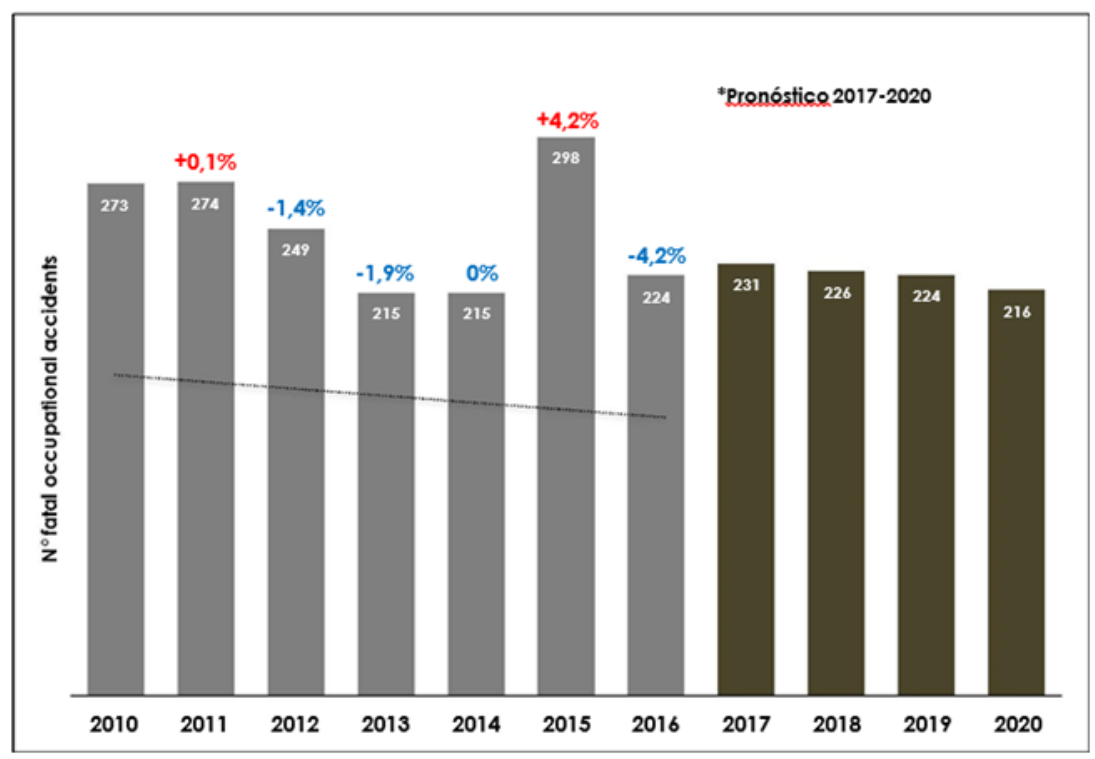

Figure 1. Temporal Distribution of fatal occupational accidents in Ecuador, 2010-2020.

* Estimation of FOA in Ecuador: 2017-2020.

Figure 3 shows the main provinces with higher mortality rates due to work injuries in 2012; Bolívar (4,9), Sucumbíos (3,3) and Napo (2,7), Loja (2,6), Morona Santiago (2,4), Cotopaxi (2,2), Orellana (2,2) and Esmeraldas (1,7). In 2013, Bolívar (4,7), Morona Santiago $(2,9)$ and El Oro $(2,9)$ stand out as the provinces with greater rates.

For 2014 we can appreciate a raise in the Mortality Rates of the Amazon Region Provinces, especially in Morona Santiago, Pastaza, Orellana and Sucumbíos, Fig. 4. Finally, in 2016 the main provinces with higher Mortality Rates were Napo (5,0), Los Ríos (3,7), Pastaza $(2,4)$ and Galápagos $(2,3)$, Figure 5. 
Table 1. Distribution of fatal occupational accidents and IESS affiliated workers by province per year.

\begin{tabular}{|c|c|c|c|c|c|c|c|c|c|c|c|c|c|c|c|c|c|c|c|c|c|}
\hline \multirow{2}{*}{ Provincia } & \multicolumn{3}{|c|}{2010} & \multicolumn{3}{|c|}{2011} & \multicolumn{3}{|c|}{2012} & \multicolumn{3}{|c|}{2013} & \multicolumn{3}{|c|}{2014} & \multicolumn{3}{|c|}{2015} & \multicolumn{3}{|c|}{2016} \\
\hline & $n$ & 9on & TBNR.a & $n$ & \%ั & TBNR.s & $n$ & Son & TBVR.a & $n$ & क्रn & TBVR.s & $\pi$ & क्रn & TBNR.s & $n$ & \%ก & TBVR.a & $n$ & कूn & TBVR.g \\
\hline Azuay & 17 & 6,256 & 115.546 & 17 & 6,25 & 126.682 & 18 & 7,256 & 137.282 & 11 & 5,196 & 150.937 & 13 & 6,056 & 175.176 & 13 & 4,45 & 184.401 & 10 & 4,55 & 184.401 \\
\hline Bolivar & 0 & 0,05 & 12.031 & 2 & 0,75 & 13.184 & 7 & 2,85 & 14.349 & 7 & 3,356 & 14.905 & 5 & 2,356 & 23.678 & 2 & 0,75 & 16.276 & 1 & 0,45 & 16.276 \\
\hline Coñor & 2 & 0,75 & 22.688 & 3 & 1,156 & 24.477 & 2 & 0,85 & 26.133 & 5 & 2,356 & 29.145 & 5 & 2,35 & 41.302 & 8 & 2,75 & 36.827 & 5 & 2,25 & 36.827 \\
\hline Carchi & 5 & 1,85 & 13.841 & 4 & 1,56 & 14.723 & 0 & 0,050 & 15.798 & 2 & 0,95 & 16.998 & 1 & $0,5 \%$ & 25.049 & 0 & 0,050 & 18.589 & 0 & 0,05 & 18.589 \\
\hline Chimborozo & 3 & 1,156 & 35.993 & 7 & 2,65 & 39.030 & 5 & 2,05 & 43.538 & 4 & 1,996 & 45.672 & 2 & 0,95 & 76.566 & 17 & $5,7 \%$ & 52.908 & 3 & 1,35 & 52.908 \\
\hline Cotopoxi & 8 & 2,95 & 38.108 & 12 & 4,45 & 42.100 & 10 & 4,056 & 45.087 & 13 & 6,056 & 49.468 & 5 & 2,35 & 83.961 & 11 & $3,7 \%$ & 56.738 & 9 & 4,050 & 56.738 \\
\hline E Oro & 15 & $5,5 \%$ & 61.721 & 14 & 5,196 & 70.290 & 13 & 5,25 & 81.854 & 25 & 11,67 & 86.644 & 14 & $6,5 \%$ & 133.096 & 23 & 7,75 & 110.039 & 15 & 6,75 & 110.039 \\
\hline Esmeraldos & 0 & 0,050 & 35.906 & 4 & 1,55 & 38.875 & 7 & 2,85 & 41.415 & 1 & $0,5 \%$ & 44.223 & 8 & $3,7 \%$ & 73.387 & 8 & 2,75 & 50.476 & 7 & 3,15 & 50.476 \\
\hline Golápogos & 0 & 0,05 & 5.243 & 0 & 0,05 & 5.471 & 0 & 0,056 & 6.205 & 0 & 0,05 & 6.630 & 0 & 0,05 & 11.693 & 0 & 0,05 & 8.659 & 2 & 0,95 & 8.659 \\
\hline Guayos & 77 & 28,25 & 558.439 & 66 & 24,190 & 594.287 & 69 & 27,75 & 655.362 & 43 & 20,05 & 693.143 & 42 & $19,5 \%$ & 833.520 & 59 & 19,85 & 843.824 & 36 & 16,190 & 843.824 \\
\hline Imbabura & 5 & 1,85 & 41.685 & 9 & 3,35 & 44.642 & 6 & 2,45 & 50.235 & 5 & 2,356 & 54.891 & 5 & 2,35 & 75.482 & 3 & 1,050 & 61.678 & 5 & 2,25 & 61.678 \\
\hline Lojo & 6 & 2,25 & 42.808 & 10 & 3,65 & 45.972 & 14 & 5,650 & 53.245 & 6 & 2,85 & 57.907 & 5 & 2,35 & 79.778 & 7 & 2,350 & 62.416 & 8 & 3,65 & 62.416 \\
\hline Los Ríos & 5 & 1,856 & 51.362 & 6 & 2,25 & 51.483 & 0 & 0,056 & 58.068 & 2 & 0,95 & 63.339 & 17 & 7,956 & 109.378 & 12 & 4,05 & 74.698 & 28 & $12,5 \%$ & 74.698 \\
\hline Manabí & 12 & 4,45 & 104.368 & 16 & 5,85 & 126.682 & 16 & 6,45 & 134.287 & 19 & 8,85 & 143.668 & 28 & 13,05 & 207.038 & 14 & 4,75 & 223.309 & 8 & 3,65 & 223.309 \\
\hline Morona Santiago & 0 & 0,050 & 9.572 & 4 & 1,55 & 10.582 & 3 & 1,25 & 12.344 & 4 & 1,950 & 13.574 & 3 & 1,45 & 16.493 & 3 & 1,05 & 15.569 & 3 & 1,35 & 15.569 \\
\hline Nopo & 4 & $1,5 \%$ & 8.872 & 2 & $0,7 \%$ & 9.753 & 3 & 1,25 & 10.945 & 0 & 0,05 & 11.999 & 0 & 0,050 & 13.064 & 17 & $5,7 \%$ & 14.019 & 7 & 3,150 & 14.019 \\
\hline Orellana & 1 & 0,45 & 10.244 & 3 & 1,15 & 11.906 & 3 & 1,25 & 13.543 & 2 & 0,95 & 17.435 & 4 & 1,95 & 24.337 & 4 & 1,35 & 17.727 & 3 & 1,35 & 17.727 \\
\hline Postoza & 1 & 0,45 & 8.500 & 0 & 0,05 & 9.100 & 0 & 0,05 & 10.386 & 1 & 0,55 & 10.781 & 2 & 0,95 & 11.549 & 5 & $1,7 \%$ & 12.406 & 3 & 1,35 & 12.406 \\
\hline Pichincho & 91 & 33,35 & 762.330 & 63 & 23,050 & 799.628 & 56 & $22,5 \%$ & 903.084 & 53 & $24,7 \%$ & 945.546 & 37 & 17,25 & 1.099 .730 & 60 & 20,15 & 1.069 .032 & 46 & $20,5 \%$ & 1.069 .032 \\
\hline Sonto Elena & 0 & 0,05 & 15.596 & 4 & 1,55 & 16.766 & 0 & 0,050 & 19.813 & 1 & 0,55 & 22.343 & 3 & 1,465 & 84.076 & 3 & 1,05 & 27.834 & 2 & 0,95 & 27.834 \\
\hline Santo Domingo Tsóchilas & 7 & 2,656 & 34.105 & 0 & 0,05 & 36.444 & 2 & 0,85 & 40.449 & 0 & 0,05 & 44.544 & 3 & 1,46 & 52.306 & 9 & $3,0 \%$ & 53.341 & 11 & 4,956 & 53.341 \\
\hline Sucumbíos & 3 & 1,150 & 13.648 & 13 & $4,7 \%$ & 15.078 & 6 & 2,45 & 18.351 & 2 & 0,95 & 21.645 & 4 & $1,9 \%$ & 23.015 & 6 & $2,0 \%$ & 25.026 & 5 & 2,26 & 25.026 \\
\hline Tungurahuo & 11 & 4,05 & 62.033 & 12 & 4,45 & 68.195 & 9 & 3,65 & 78.013 & 8 & $3,7 \%$ & 82.167 & 6 & $2,8 \%$ & 98.321 & 11 & $3,7 \%$ & 93.240 & 6 & $2,7 \%$ & 93.240 \\
\hline Zomoro Chinchipe & 0 & 0,050 & 8.667 & 3 & 1,15 & 9.280 & 0 & 0,05 & 10.935 & 1 & 0,55 & 12.169 & 3 & 1,456 & 14.726 & 3 & $1,0 \%$ & 16.572 & 1 & 0,45 & 16.572 \\
\hline
\end{tabular}

a Workers affiliated to the Ecuadorian Institute of Social Security per year and province.

b Workers affiliated to the Ecuadorian Institute of Social Security in 2015. 


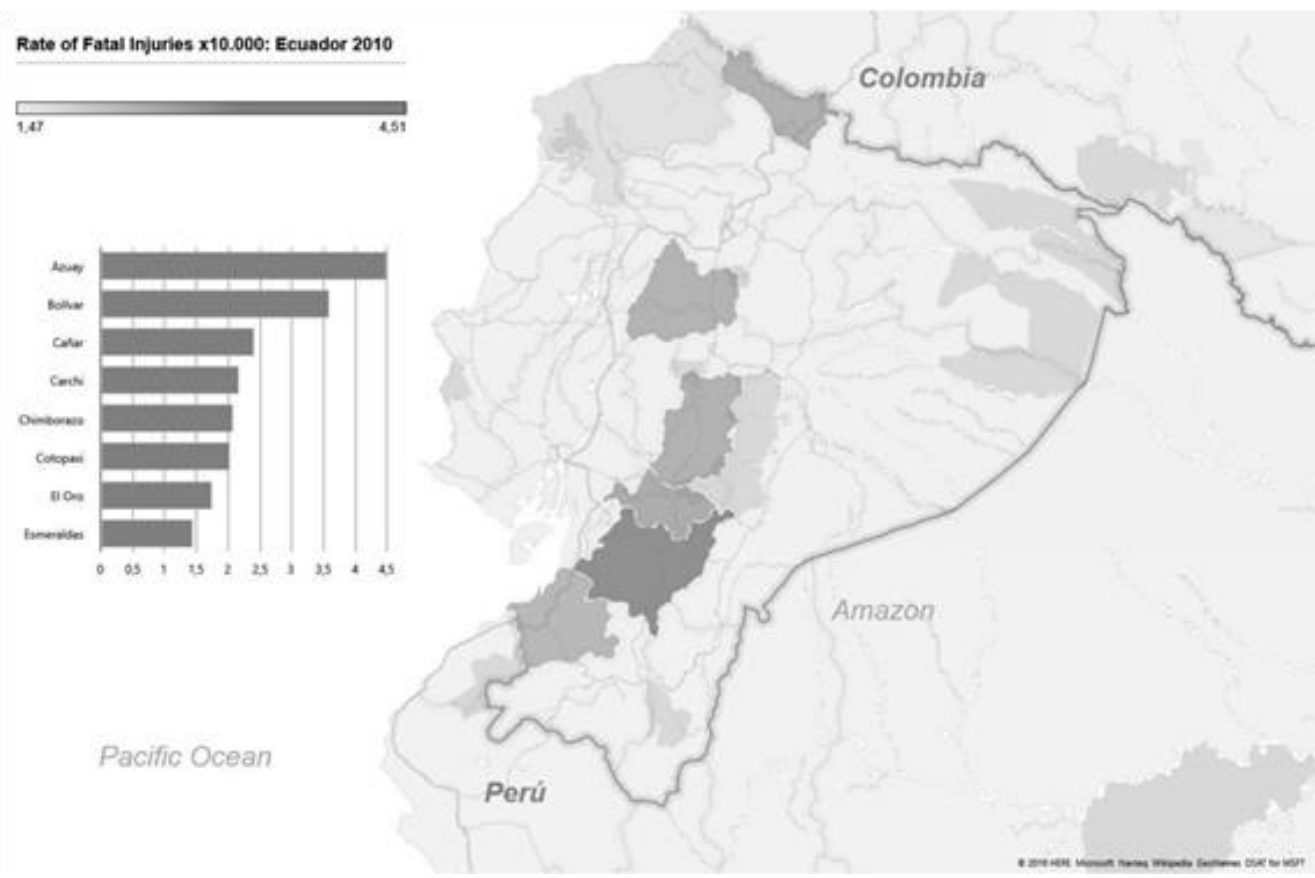

Figure 2. Adjusted Rate of Fatal Work injuries: main provinces in 2010.

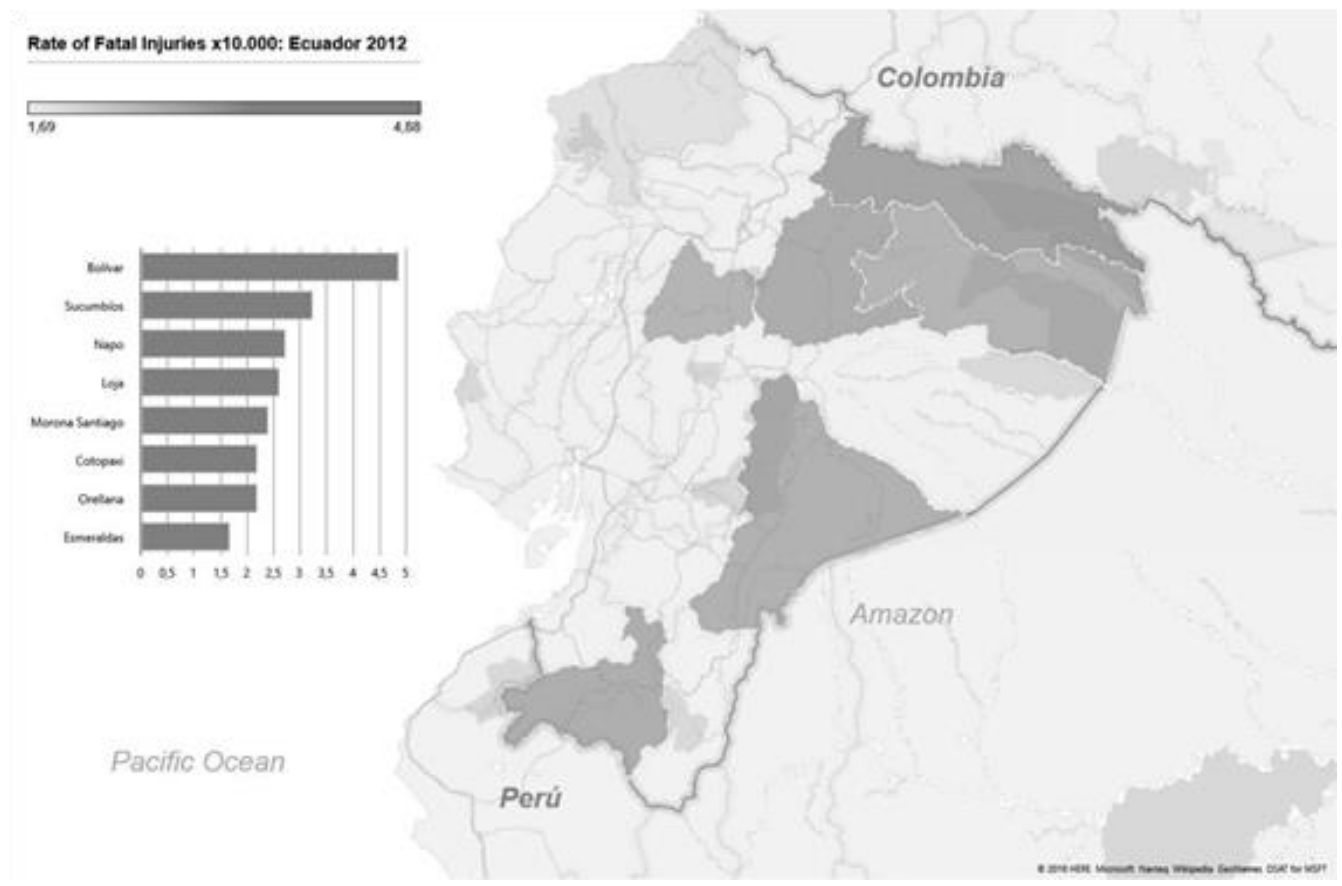

Figure 3. Adjusted Rate of Fatal Work injuries: main provinces in 2012. 


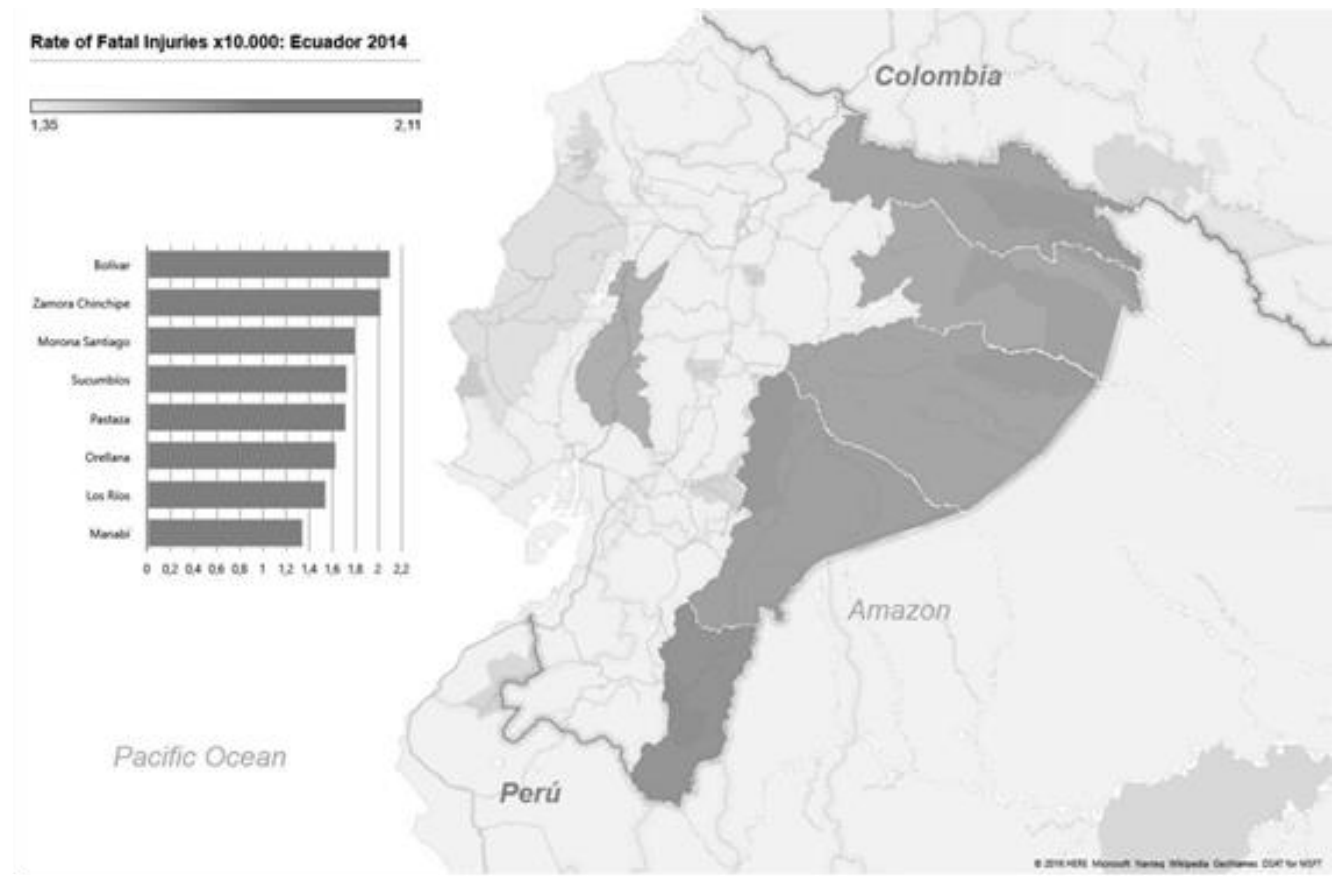

Figure 4. Adjusted Rate of Fatal Work injuries: main provinces in 2014.

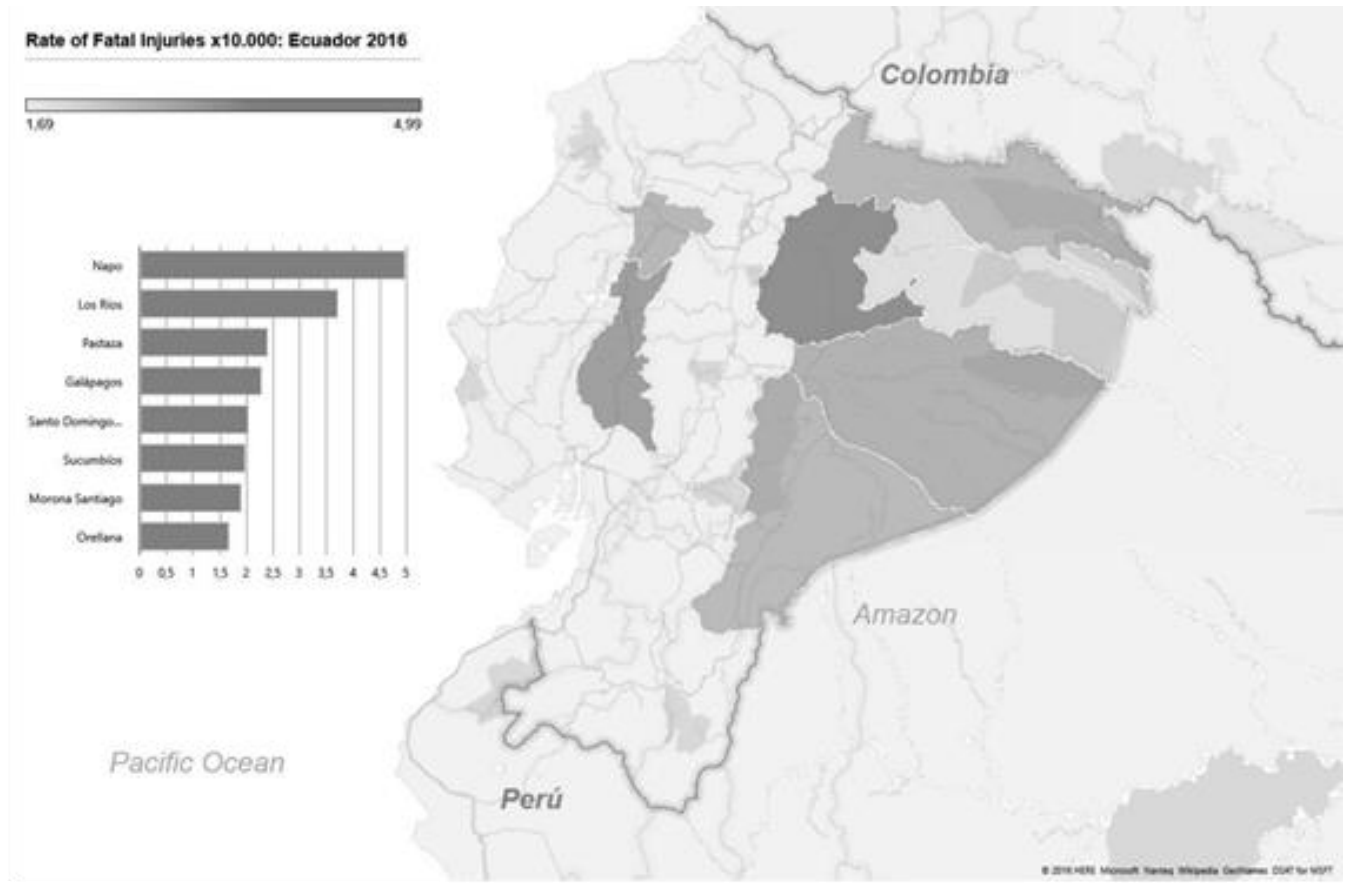

Figure 5. Adjusted Rate of Fatal Work injuries: main provinces in 2016.

\section{Conclusions}

Ecuador has a total area of $270.670 \mathrm{Km} 2$, including the Galapagos Islands $(7.844 \mathrm{Km} 2)$. It is considered a small country compared to Colombia and Peru. The Andean Mountain Range, implying important differences in terms of cultural diversity and fatal work accident distribution by provinces, divides the country geographically. 
Between 2010 and 2016 there have been 1.748 dead workers in consequence to work injuries, with an average of $250 \pm 33$ deaths per year, being 2015 the year with higher mortality, 298 deaths, and Pichincha $(n=406)$, Guayas $(n=392)$, El Oro $(n=119)$, Manabí $(n=113)$ and Azuay $(n=99)$ the provinces that registered the greater number of fatalities.

The enforcement of Resolutions 333 and 390 [21,25-26] (2010 y 2011, respectively) had a significant impact on the decrease of deaths due to work injuries in the years to follow, keeping a reduction tendency until 2015. This happened mainly due to principal matters: first, the characteristics of these legal norms compel enterprises to implement an occupational health and safety management system allowing the control of risk factors at their workplaces [27-28]; the second issue relies in the awareness campaigns and training performed by IESS nationwide during these years.

In 2014, both Resolutions were reinforced with the implementation of a National System of Occupational Risk Prevention Management [29] (SGP), again forcing employers to perform self-audits on the risk prevention management of their businesses to reduce occupational accident rates through the identification, measurement, evaluation and control of the existing workplace risks [30].

Despite the public initiatives of this year, the noncompliance of businesses in the effective application of the principles of a preventive action was demonstrated, triggering an increase in labor injuries: fatalities $(2014=215 ; 2015=298)$, work injuries $(2014=23.093$; 2015=24.379) and occupational diseases (2014=704; 2015=892) [22], without considering possible sub-notifications [31-32].

Early 2016, the Management Board of IESS overturned the Resolutions of 20102011 and the SGP by Resolution No. C.D. 513 - Regulations of the Occupational Risk General Insurance [33], emphasizing again on the integration of preventing measures in all phases of labor processes, observing a small descent of FOA with respect to the prior year.

Related to regional economic activities, it is interesting to highlight that Morona Santiago, Napo, Orellana, Pastaza and Sucumbios provinces are characterized by being areas of oil exploitation, the province of Cañar a mining and quarries exploitation area, and Cotopaxi, Guayas and Pichincha areas of manufacturing industries mainly. These aspects are associated to the number of FOA in the period of study.

Even if it is not the object of this research, diverse study prove the relationship between the implementation of occupational health and safety management systems and business productivity [34-35]; similarly between the FOA timing with the fluctuation in the implementation and derogation of legal norms in the matter of study.

FOA is just one of the problematic facets for the country. Occupational accidents and diseases are generating disabilities in the working population, production losses for enterprises due to work absenteeism and an unknown impact on health. All of this due to the non- 
compliance of politics by employers and lack of inspections from public control organisms, among other aspects.

FOA temporal distribution and geographic representation will allow the Ecuadorian Social Security Institute, the Labor Ministry and the Public Health Ministry to identify areas with high mortality rates and determine regulatory actions in safety and occupational health for Ecuador. At the same time, the results of this study will orient the development of future research guidelines.

Finally, it is important to perform an appropriate FOA follow-up from its temporal and geographic distribution. It is needed for the changes of the legal norms in the country and the economic dynamics characterized in the XXI century. It will deepen the analysis to broaden the knowledge on this social issue8-34.

\section{Conflicts of interest}

All authors have no conflicts of interest to declare.

\section{Bibliography}

Instituto Oceanográfico de la Armada. Derrotero de las Costas Ecuatorianas. Instituto Oceanográfico de la Armada. INOCAR; 2012. [cited 4 July 2016]. Available from: http://www.inocar.mil.ec/docs/derrotero/derrotero_cap_I.pdf

López Cevallos D, Chunhuei C, Ortega F. Consideraciones para la transformación del sistema de salud del Ecuador desde una perspectiva de equidad. Revista de Salud Pública. 2014; 16(3): 347-360.

Instituto Nacional de Estadística y Censos. [cited 12 July 2016]. Available from: http://www.ecuadorencifras.gob.ec/estadisticas/

Organización Internacional del Trabajo. Seguridad y salud en el trabajo [cited 17 July 2016]. Available from: http://ilo.org/global/topics/safety-and-health-atwork/lang--es/index.htm

XX Congreso Mundial sobre Seguridad y Salud en el Trabajo 2014 [cited 19 July 2016]. Available from:https://www.safety2014germany.com/es/vistageneral/vista-general.html

Organización Internacional del Trabajo. Salud y seguridad en trabajo en América Latina y el Caribe [cited 18 July 2016]. Available from: http://ilo.org/americas/temas/salud-y seguridad-en-trabajo/lang-es/index.htm

Hämäläinen P, Takala J, Saarela KL. Global estimates of fatal work-related diseases. Am J Ind Med. 2007; 50(1): 28-41.

Leigh JP. Economic burden of occupational injury and illness in the United States. Milbank Q. 2011; 89(4): 728-772. 
Duque De Voz N, Yánez Contreras M. Perspectivas diferenciadas del análisis de la accidentalidad laboral. Gaceta Laboral. 2015; 21(3): 313-331.

Gervais R, Pawlowska Z, Bojanowski R, Murray M, Van den Broek K. Occupational safety and health and economic performance in small and medium-sized enterprises: a review.

European Agency for Safety and Health at Work, 2009. [cited 14 May 2016]. Available from: https://osha.europa.eu/sites/default/files/publications/documents/en/publicati ons/reports/TE-80-09-640

ENN_occupational_safety_health_economic_performance_small_medium_size d_enterprises_review/OSH\%20SME\%20REPORT\%20\%20FINAL\%20020609.pdf

Benavides F., Delclos J, Benach J, Serra C. Lesiones por accidentes de trabajo, una prioridad en salud pública. Revista Española de Salud Pública. 2006; 80(5): 553-565.

Observatorio Iberoamericano de Riesgos Profesionales. Organización Iberoamericana de Seguridad Social [cited 21 Sep 2016]. Available from: http://www.oiss.org/estrategia/siarin

Manu PA1, Ankrah NA, Proverbs DG, Suresh S. Investigating the multi-causal and complex nature of the accident causal influence of construction project features. Accid Anal Prev. 2012; 48: 126-133.

Sousa Santana V, Villaveces A, Bangdwala SL, Runyan CW, Albuquerque Oliveira PR. Incidence of severe work-related injuries among young adult workers in Brazil: analysis of compensation data. Inj Prev. 2012; 18(4): 221-227.

Byler C, Kesy L, Richardson S, Pratt SG, Rodríguez Acosta RL. Work-related fatal motor vehicle traffic crashes: Matching of 2010 data from the Census of Fatal Occupational Injuries and the Fatality Analysis Reporting System. Accid Anal Prev. 2016; 92: 97-106.

Swanton AR, Young TL, Peek Asa C. Characteristics of Fatal Agricultural Injuries by Production Type. J Agric Saf Health. 2016; 22(1): 75-85. Riaño Casallas MI, Palencia Sánchez F. Dimensión económica de la seguridad y la salud en el trabajo: una revisión de literatura. Rev. Gerenc. Polít. Salud. 2016; 15(30): 24-37.

Zangirolani, LT, Cordeiro Medeiros R, Tavares de Ma CS. Spatial distribution of risks for work related injuries in a city of Southeastern e Brazil. Revista de Saúde Pública. 2008; 42(2): 287-293.

Hernández Vásquez A, Díaz Seijas D, Vilcarromero S, Santero M. Distribución espacial de los accidentes y enfermedades relacionados con el trabajo en el Perú, 2012-2014. Rev Peru Med Exp Salud Publica. 2016; 33(1): 106-112. 
Bande R, López Mourelo E. (2014): The spatial distribution of workplace accidents in Spain: assessing the role of workplace inspections [cited 4 Oct 2016]. Available from: https://mpra.ub.unimuenchen.de/56767/1/MPRA_paper_56767.pdf

Instituto Ecuatoriano de Seguridad Social. Reglamento para el Sistema de Auditoría de Riesgos del Trabajo. Resolución No. C.D. 333; 2010.

Instituto Ecuatoriano de Seguridad Social. Estadísticas. [cited 1 August 2016]. Available from: http://sart.iess.gob.ec/SRGP/indicadores_ecuador.php\#

Instituto Ecuatoriano de Seguridad Social. Ley 55 de Seguridad Social de 2001.

Instituto Ecuatoriano de Seguridad Social. Rendición de cuentas para el período 2013 a 2015. Direcciones Provinciales de Riesgos del Trabajo [cited 11 August 2016]. Available from: https://www.iess.gob.ec/es/rendicion-de-cuentas2015

Instituto Ecuatoriano de Seguridad Social. Reglamento General del Seguro General de Riesgos del Trabajo. Resolución No. C.D. 390. IESS; 2011 [cited 30 August 2016].

Instituto Ecuatoriano de Seguridad Social. Instructivo de Aplicación del Reglamento para el Sistema de Auditoría de Riesgos del Trabajo - SART, expedido mediante Resolución Administrativa No. 12000000-536 de 29 de julio del 2011.

Comunidad Andina de Naciones. Instrumento Andino de Seguridad y Salud en el Trabajo. Decisión $\mathrm{N}^{\circ}$ 584. CAN; 2004. [cited 2 August 2016]. Available from: http://www.comunidadandina.org/camtandinos/ola/ISociolaborales.asp?Mn $\mathrm{uSup}=4 \& \mathrm{IS}=3 \& \mathrm{IA}=3$.

Comunidad Andina de Naciones. Reglamento del Instrumento Andino de Seguridad y Salud en el Trabajo. Resolución $\mathrm{N}^{\circ}$ 957. CAN; 2005. [cited 2 August 2016]. Available from: http://www.comunidadandina.org/camtandinos/ola/ISociolaborales.asp?Mn $\mathrm{uSup}=4 \& \mathrm{IS}=3 \& \mathrm{IA}=3$.

Instituto Ecuatoriano de Seguridad Social. Registro Oficial N 196 del 06 del marzo de 2014. AutoAuditorias Sistema Nacional de Gestión de Prevención de Riesgos Laborales.

Instituto Ecuatoriano de Seguridad Social. Sistema Nacional de Gestión de Prevención de Riesgos Laborales. [cited 25 August 2016]. Available from: https://sart.iess.gob.ec/autoauditoria_v2/tutoriales/Tutorial.pdf

Hämäläinen P, Takala J \& Saarela KL. Global estimates of fatal work-related diseases. Am J Ind Med. 2007; 50(1): 28-41.

Salinas Tovar JS, López Rojas P, Soto Navarro MO, Caudillo Araujo DE, Sánchez Román FR y Borja-Aburto VH. El subregistro potencial de accidentes de trabajo en el Instituto Mexicano del Seguro Social. Salud Pública de México. 2004; 46: 204-209. 
Instituto Ecuatoriano de Seguridad Social. Reglamento del Seguro General de Riesgos del Trabajo. Resolución No. C.D. 513. IESS; 2016 [cited 30 August 2016]. Available from: http://sart.iess.gob.ec/DSGRT/norma_interactiva/IESS_Normativa.pdf

Takala J, Hämäläinen P, Saarela KL, Yun LY, Manickam K, Jin TW, et al. Global estimates of the burden of Injury and illness at work in 2012. J Occup Environ Hyg. 2014; 11(5): 326-337.

González Delgado M, Gómez Dantes H, Fernández Nino JA, Robles E, Borja VH, Aguilar M. Factors associated with fatal occupational accidents among Mexican workers: a national analysis. PloS One. 2015; 10(3): e0121490.

Gómez García, A.R. y Suasnavas Bermúdez, P.R. Incidencia de Accidentes de Trabajo Declarados en Ecuador en el Período 2011-2012. Ciencia \& Trabajo. 2015; 52(5): 49-53. 